\title{
Practical Tools for Content Development: Pre-Service Teachers` Experiences and Perceptions
}

\author{
Zeynep Yurtseven Avci \\ Asst. Prof., Eskisehir Osmangazi University, Turkey, zavci@ogu.edu.tr \\ Esra Eren \\ Asst. Prof., Eskisehir Osmangazi University, Turkey, eeren@ogu.edu.tr \\ Munise Seckin Kapucu \\ Asst. Prof., Eskisehir Osmangazi University, Turkey, muniseseckin@hotmail.com
}

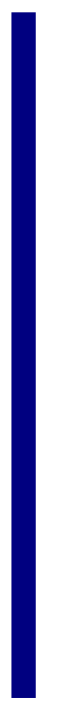

This study adopts phenomenology approach as the research design method to investigate pre-service teachers` experiences and perceptions on using practical tools for content development. The participants are twenty-four pre-service teachers who were taking Computer II course during 2013-2014 spring semester at a public university in Turkey. During the course, they were introduced several practical tools, which we define as mostly internet-based technologies that do not require installation or having any computer programming skills. Pre-service teachers prepared contents specific to their fields for homework and projects. At the end of the semester individual interviews were conducted with the participants. Content analysis method was used to analyze the data. According to the results, they enjoyed creating contents using these tools. At the same time, they had some difficulties. Majority of the participants perceive presentation, animation, cartoon creation tools to be most beneficial to improve student learning. Some of the positive outcomes they foresee when these technologies are used in the classroom are: higher student engagement, active participation, reinforcement, deeper understanding, and development of imagination skills. It is believed that the findings of this study will contribute to the development of teacher preparation programs for effective use of technology especially for content development.

Key Words: pre-service teachers, practical tools, content development, experience, perception, Web 2.0.

\section{INTRODUCTION}

Competencies of information and communication technologies (ICT) are recognized as one of the nine general competencies for teachers and it is essential for integration of technology in their future teaching for pre-service teachers (Aslan \& Zhu, 2016; Selvi, 2010). Xiong and Lim (2015) indicate the importance of teacher education programs on different aspects of pre-service teachers' learning outcomes and Aslan and Zhu (2016) present the significant role of ICT-related courses on pre-service teachers' teaching 
practices. According to Tondeur et al. (2011), even if many institutions offering educational technology courses for pre-service teachers to help them develop technology skills, pre-service teachers still do not feel prepared for using technology in the classroom. The authors suggest that "pre-service teacher education should not only focus on how to use technology, but also how technology can be used for teaching and learning" (p. 2). According to Xiong and Lim (2015) "feedback and reflections from pre-service teachers' ICT learning experiences are essential to revise and refine teacher education program" (p. 25). In this regard, it is critical to investigate pre-service teachers` experiences with contemporary technologies in their technology related courses not only to predict their level of technology integration as future teachers, but also to identify certain needs in teacher education programs for supporting pre-service teachers and improving their future technology applications.

New generation of pre-service teachers who were born after 1980 and surrounded by digital technologies from their birth are named as "digital natives", but limited empirical studies are available on their competencies and experiences with digital technologies (Chen, Lim \& Tan, 2010; Prensky, 2001). Chen, Lim and Tan (2010) report that even if digital technologies impact multiple aspects of pre-service teachers` lives critically, there is an important gap between their everyday experience with technology and their technology use for educational purposes. The authors claim that small number of preservice teachers concentrate on content creation activities using digital technologies. They report about twenty-three percent of the pre-service teachers who participated in the study have never created a website, nineteen percent have never produced a video, eighteen percent have never created an online mindmap, eleven percent have never created an audio podcast, and so on.

In Turkey, with Movement of Enhancing Opportunities and Improving Technology (FATIH) project, many classrooms have been equipped with interactive whiteboards (IWBs) and tablet computers have been distributed to students and teachers. Infrastructure work and pilot applications were started in 2010. Implication of FATIH project necessitate effective teacher professional development and development of appropriate and adequate e-content (Banoglu, Madenoglu, Uysal \& Dede, 2014; Kayaduman, Sarikaya, \& Seferoglu, 2011; Keles, Oksuz \& Bahcekapili, 2013). Although Ministry of National Education (MoNE) organizes teacher trainings and make effort to provide e-content through collaboration with some private organizations; studies report low knowledge, skills, experience, and self-efficacy of teachers for using IWBs and tablets and e-content development (Bulut \& Kocoglu, 2012; Keles et al., 2013; Kurt, Kuzu, Dursun, Gullepınar, \& Gultekin, 2013). Inadequate technology competencies are reported for pre-service teachers as well (Aksut, Keyvanoglu \& Balikci, 2013; Besoluk, Kurbanoglu \& Onder, 2010). Additionally, the need for training pre-service teachers for using information and communication technologies, and econtent development is recognized by several studies (Balci, Gokkaya, \& Kar, 2013; Cuhadar \& Yucel, 2010; Goktas, Yildirim \& Yildirim, 2009; Tondeur et al., 2011).

We define practical tools for content development as the tools that are mostly internetbased; basic computer skills are usually adequate to use them, programming skills are 
not required; and development of content with them is easy and do not take much time (Eren, Yurtseven Avci \& Seckin Kapucu, 2014; Eren, Yurtseven Avci, \& Seckin Kapucu, 2015). Cicek and Yazar (2013) used this term for the first time. From the definition, most of these tools emerge as Web 2.0 technologies such as interactive presentation tools (e.g. Voice Thread), cartoon tools (e.g. ToonDoo), and online concept map tools (e.g. Gliffy). Murugesan (2007) reports that these tools have gained the attention of people from various fields including business people, IT professionals and general Web users. The author provides other names used for Web 2.0 tools as following: "the wisdom Web, people-centric Web, participative Web, and read/write Web" (p. 34). In this sense, these technologies promote more collaborative work, allow social interaction around many forms of media. Users have more opportunities to create creative and rich content in different forms; and they additionally allow reusing and modifying the content that is already available through the net. There are also technologies that are mentioned later in this study which are not Web 2.0 tools, but they still align with our definition for practical tools for content development such as Movie Maker, Windows Sound Recorder, and Publisher.

The term practical tools for content development is newly introduced in the literature. Thus we do not see studies about these technologies, but a good amount of literature is available on Web 2.0 technologies. Studies report that Web 2.0 offer a broad range of possibilities for effective teaching and learning activities (Butler, 2012; Hew \& Cheung, 2013, Meyer, 2010). However, Butler (2012) claims that many new teachers come into the field without knowing how to integrate technology, especially Web 2.0 tools, into teaching. There are some attempts to educate pre-service teachers about these technologies and understand their insights (e.g. Baltaci-Goktalay \& Ozdilek, 2010; Eyyam, Menevis, \& Dogruer, 2011; Hartshorne \& Ajjan, 2009), but definitely we need more and deeper research on pre-service teachers` experiences and opinions about these tools to shape teacher education programs accordingly.

Goktas, Yildirim, and Yildirim (2008) suggest that pre-service teachers should be trained during their teacher education experience to use ICT effectively for their future students. According to Goktas, Yildirim \& Yildirim (2009), more ICT-related courses are needed in teacher education programs and those courses should be more practiceoriented. Computer II course is one of the courses that students from all different departments of College of Education are taking in their first or second year. During the spring 2014 semester, pre-service teachers who were taking Computer II class at a university in Central Turkey were introduced several practical tools for content development. Most of these tools are internet-based applications and usually Web 2.0 technologies including presentation tools (e.g. Prezi, Voice Thread), animation creation tools (e.g. GoAnimate), e-book creation tools (e.g. Flipbook), online concept map preparation tools (e.g. Gliffy), creating avatars (e.g. Voki), creating cartoons (e.g. ToonDoo), and several Google Applications etc. In the class, pre-service teachers prepared contents specific to their fields for homework and projects. This study investigates pre-service teachers' experiences using practical tools for content development during Computer II course and analyzes their opinions about usefulness of those technologies in their fields. For this purpose, the following questions were 
addressed: What are the pre-service teachers`opinions about using practical tools for content development? What are the pre-service teachers` opinions about pros and cons of using content that was created using practical tools in their field of study? Which type of challenges did pre-service teachers face, while using these technologies? What are the pre-service teachers` plans in terms of using these tools in their future teaching and suggestions about using these tools in education?

\section{METHOD}

\section{Research Design}

This study adopts phenomenology approach as the research design method to investigate pre-service teachers` experiences and perceptions on using practical tools for content development. According to Creswell (2013), phenomenology is used to reveal the meanings that individuals attributed to a phenomenon, fact, or concept. In this sense, 'using practical tools for content development' handled as a phenomenon and participants` experiences and perceptions are portrayed based on their own explanations.

\section{Participants}

Sixteen freshmen and eight sophomores, twenty-four students in total, from College of Education at a university in Turkey participated in this study. Eight of the participants were from Science and Technology Education (33\% of whole class), five of them were from Mathematics Education (21\%), seven of them from Elementary Education (29\%) and four participants (17\%) were from English Education department. Criteria sampling, which is a purposive sampling method, was used to select the sample. The main criterion was set as taking Computer II course. Since the participation in the study was voluntarybased, the number of participants from different departments was not the same; but participation from each department was at least $10 \%$ of the whole class for each group. $17(71 \%)$ of the participants are female and 7 (29\%) of them are male.

\section{Procedures}

During the spring 2014 semester four classes were taking Computer II class with the same instructors. Two of the researchers were the instructors of the course. Class instruction was mostly performed by one of the researchers. Whole semester was around 14 weeks (3,5 months). During this period pre-service teachers were introduced several tools for content development. Most of these tools are internet-based applications and usually Web 2.0 technologies including presentation tools (e.g. Prezi, Voice Thread), animation creation tools (GoAnimate), e-book creation tools (e.g. Flipbook), online concept map preparation tools (e.g. Gliffy), tools for creating avatars (e.g. Voki), tools for creating cartoons (e. g. Toondoo), Google applications etc. Those technologies are categorized and presented in Figure 1.

In-class sessions were based on application by the instructor and students synchronously. While the instructor was demonstrating each single step to use the tools, students followed the instructor from the big screen that was connected to a projector. Individual help was provided to students by the second instructor as needed. Students were required to complete a small in class assignment for each tool they had learned about; then they had weekly homework to create learning materials related a topic from 
their particular field of study using the tools. Students were submitting their assignments through the Moodle system. In-class and outside of the class assignments were graded regularly and grades were announced in the classes' Moodle sites.

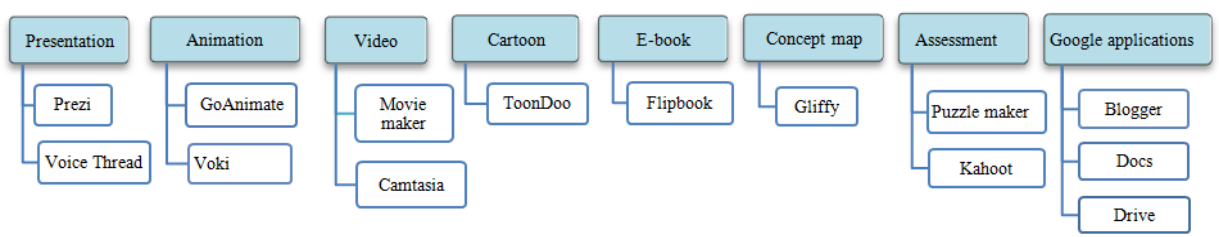

Figure 1: Content Development Tools

\section{Instruments}

Semi-structured interviews were conducted with each pre-service teacher who participated in this study. The interview protocol form that was developed by the researchers, consists of eight questions related with pre-service teachers` experiences on using the practical tools, their prior experiences with the tools, which tools they found more beneficial specifically for their fields of study, pros and cons of using contents developed using these tools, which kind of problems they faced while using these tools and their future plan regarding using these tools.

\section{Data Collection}

The individual, face-to-face interviews were conducted at the end of the semester. The duration of the interviews was around 15 minutes. At the beginning of the interviews participants were informed briefly about the purpose of the study and their participation is optional and would not affect anything about the course they are taking and their grades. They were also informed that their names will not be used in reporting and they will be given coded differently. In this way they are assured about the confidentiality of the study. Additionally, it was shared with participants that the purpose of recording was saving time during the interview and accurate analysis of the findings. After these procedures participants were asked to read and sign a consent form including all the information given them about the study and their volunteer participation. During the interviews, voice recorder was used with the permission of the participants. During the interviews, situations that may affect data collection process negatively were avoided.

\section{Data Analysis}

Content analysis method was used to analyze the interview data. According to Glesne (1999) during the process of data analysis a researcher needs to categorize, synthesize, search for patterns, and interpret the data collected. The audio recordings were listened by the researchers and open coded with anecdotal notes. Then the recordings and notes were compared by an expert for accuracy check. On the second phase, all categories from the coding were organized and summarized under themes based on their concept, and some explanations were added (Miles \& Huberman, 1994). Finally, coding and themes were compared and main themes were decided. While recording categories and 
themes were supported by participants` actual words. When reporting from participants, their credentials were not given, instead they were coded with random numbers (e. g. S1). At the end of coding researchers reviewed the codes and agreed on them.

For the internal validity of the study; for the interview questions, for the consistency between coding made with raw data, and for the obtained results experts were consulted. Participants` perceptions were first defined from direct quotations, and then interpreted. For the accuracy, the researchers listened the audio recordings several times for the consistency with the participants` words. For the external validity; the method including research design, participants, data collection procedures, instrument, data analysis procedures and findings are presented in detail (Miles \& Huberman, 1994). To assure both internal and external validity, the number of the participants was decided accordingly. Coding of data was done by researchers at different times and was compared (Creswell, 2013). For the comparing none of the statistical methods were used, a general comparison was made and conflicting codes were recoded or removed, and general themes were decided. Interviews were completed by the researcher who was not the instructor to allow participants talking freely and interpretation of results was taken care of cautiously for objectivity.

\section{FINDINGS}

\section{Perceptions about using practical tools for content development}

In this section participants` experiences on using practical tools for content development in Computer II course are presented. First, their general opinions about these tools are given. Later, their prior experience with these technologies, the tools they liked working with most, challenges they faced, their perceptions about pros and cons about using these tools for instruction, their future plans for using these tools, and their suggestions to improve the use of these technologies for instruction are presented. Majority of the participants reported positive comments about using practical content development tools for educational purposes. The most reported reason for their positive perception was providing more visual representation of the concepts than hard copies in a fun and unique way. They suggest that higher student engagement and deeper understanding would be possible by using these technologies. Exemplar student comments are provided as follows:

I believe using these tools would be helpful when I became a teacher, because technology is in every aspect of our lives and students know it better than us. It would be easier to get their attention using these technologies. (S6, Science Education)

These technologies especially would be helpful while teaching lower grade students allowing them having fun, while learning. They are entertaining and educational. I believe they are not necessary not only for students, but for us as well...they make presentation richer. (S8, English Education)

The abstract concepts become more concrete with these tools, so that students could conceptualize more easily. (S5, Science Education) 
Pre-service teachers believe that instruction using the content prepared by practical tools would be more student-centered, engaging, and attractive through faster access to information, convenient information sharing, and collaborative work. Quotes from participants related to this concept are given below:

When we are teaching in future, teaching students with an online book or combining it with images and/or with different interactive elements would enhance the students` capacity to understand much more. (S3, Mathematics Education)

Everyone can access the content prepared with these tools. When students miss a class; they can access resources, since it is online...it is better and contemporary. (S7, English Education)

\section{Prior Experiences}

Most of the students reported that they did not have any experience with most of the practical tools that they have learned in the Computer II class. Only some students had some experience with some of the technologies. The technologies used by students before the class are: Microsoft Office, audio recording, video production (Movie Maker), Google tools (e.g. Maps), image editing (e.g. Paint), Facebook, YouTube and some other social networks.

\section{Tools that Pre-service Teachers Found more Beneficial}

Participants were much appreciated that they have learned about these technologies. The most liked tools reported by pre-service teachers are given in Table 1.

Table 1: Tools found most beneficial

\begin{tabular}{lclc}
\hline Tools & $f$ & Tools & $f$ \\
\hline GoAnimate (Animation) & 13 & Voice Thread (Interactive presentation) & 4 \\
\hline ToonDoo (Cartoon) & 9 & Flipbook (E-book preparation) & 4 \\
\hline Prezi (Presentation) & 8 & Movie Maker/ Camtasia (Video production) & 3 \\
\hline Blogger (Blog) & 7 & Voki (Avatar) & 3 \\
\hline
\end{tabular}

As seen in Table 1, pre-service teachers enjoyed most preparing content using animation and cartoon preparation tools. Major reasons for this are that these tools are visual and entertaining, and offer a rich presentation. Exemplar student comments are as follows:

If a teacher has access and time, I agree using GoAnimate. Everything is ready in the software, you just drag drop. GoAnimate is very appropriate for science teaching. An animation that you created will appeal to all 4, 5, and 6 grades...the same thing is true for ToonDoo as well. The information would stick with students much longer, since they learned visually. (S6, Science Education)

As teacher candidates we need to present something constantly. In Prezi, we could use visualization more easily and effectively. It does not take much time as PowerPoint. (S7, English Education)

During the class, pre-service teachers opened a blog account and shared the content they prepared through their blog. One of the pre-service teachers stated the importance of setting up a blog with saying: It was fun to prepare a blog. I very enjoyed that other people visited my blog. Blog is something people can access and leave comments... If 
some information is given through a blog with references, it would be helpful to me. Similarly, my blog would be helpful to others. (S6, Science Education)

\section{Pros and Cons}

Participants' responses to the question 'whether they think using the content created with practical tools would have any positive impact or not in their field' are presented in Table 2 along with frequencies.

Table 2: Pros of using content developed with these tools

\begin{tabular}{llll}
\hline Pros & $f$ & Pros & $f$ \\
\hline Engaging student attention & 9 & Serve as a model for using technology & 4 \\
\hline Knowledge retention & 9 & Multi-sensory learning & 3 \\
\hline Motivation & 8 & Higher student participation & 2 \\
\hline Variety of teaching methods & 6 & More fun & 2 \\
\hline Learning easier and faster & 5 & Development of imagination skills & 2 \\
\hline Deeper understanding and reinforcement & 5 & Knowledge sharing & 1 \\
\hline
\end{tabular}

As presented in Table 2, the themes 'engaging student attention' and 'knowledge retention through visualization and audio' have the highest frequency than the other themes. Following that pre-service teachers' beliefs saying that using variety of teaching methods would result with higher student motivation; easier, faster, and effective learning through deeper understanding and reinforcement; and learning with technology would support development of their technological skills through modeling. Some participant comments about advantages of using content prepared practical tools in teaching and learning process as follow:

The content prepared with these tools would engage more students`attention who otherwise would not be engaged. Students usually get bored of lectures: teacher present and students passively listen. Sometimes they go to board to solve a problem. However, when we prepare an entertaining presentation of information with these tools, it would be much more engaging especially for students in elementary level. (S3, Mathematics Education)

Students would learn faster; since they see and hear at the same time, you target multiple senses. Instead of writing 'father' for the translation of 'baba' (father in Turkish), they would see a representation of father and listening something from that image would increase memory retention and students would learn better. (S7, English Education)

Eleven of the twenty-four participants responded the question "whether they think using the content created with practical tools would have any negative effects or not in their field' saying: if the tools are used aligning with targeted student outcomes on timely manner, they would not have a negative effect. On the other hand, some of participants concerns are presented in Table 3 along with frequencies.

Table 3: Cons of using content developed with these tools

\begin{tabular}{llll}
\hline Cons & $f$ & Cons & $f$ \\
\hline Distracting & 3 & Laziness & 2 \\
\hline Digressing & 3 & Time consuming & 1 \\
\hline Not interesting & 2 & Addiction & 1 \\
\hline
\end{tabular}


According to Table 3, the themes 'distracting' and 'digressing' have the highest frequencies. Some exemplar quotes from pre-service teachers are given below:

They may cause distraction. If students watch the course material like a regular cartoon, instead of gaining consciousness; they might loose connection with the content. They would begin to see the course as a game. (S5, Science Education)

Individuals who development content using these tools should be cautious not to give things that would confuse children. Content prepared with these tools should be used timely, as a supportive material. Otherwise students would get bored. (S4, Mathematics Education)

Technology makes our lives easier, but too easy could make students lazy. (S7, English Education)

\section{Challenges Faced}

Six pre-service teachers reported that they did not face any challenges, while preparing content using practical tools. Some challenges and problems reported by pre-service teachers while using the practical tools for content development for the first time are presented in Table 4 under two main categories: "while learning the tools" and during the "content development process".

Table 4: Challenges faced

\begin{tabular}{llll}
\hline while learning the tools & $f$ & content development process & $f$ \\
\hline Language barrier & 7 & Limited characters available & 4 \\
\hline Having limited computer skills & 5 & Recording problems & 4 \\
\hline Internet skills & 3 & Takes time and effort & 3 \\
\hline Limited resources & 2 & Character selection & 2 \\
\hline Limitations of the certain software & 1 & Writing scenario & 2 \\
\hline
\end{tabular}

According to Table 4, pre-service teachers mostly experienced language barrier problems, since the main language of the tools was English. Participants mentioned that they learned easier when they participated in class. Otherwise, they had hard time for learning by themselves when they missed the class, since resources in Turkish are not available. Some participants challenged by internet skills such as setting up an email account and creating membership to use some online applications. Using the tools, they were also challenged to find characters, due to absence of appropriate characters for the targeted audience. Another challenge was reported as using these technologies for content development take more effort and time. Exemplar comments about challenges are provided below:

Preparing content with these tools takes time, it needs to be appropriate for the audience...for example, if I prepare something for six graders, I need to choose proper images. (S7, English Education)

The only difficulty I had using these tools was applying them to science contents, because the characters such as some animals or icons for foods are not available in the software. (S6, Science and Technology Education) 


\section{Future Plans}

Participants were asked about their plans about using these technologies for content development for their future teaching. Themes from their responses are given in Table 5 along with frequencies.

Table 5: Future plans for using practical tools for content development

\begin{tabular}{lcll}
\hline Categories & $f$ & Categories & $f$ \\
\hline Presentation tools & 19 & E-book & 7 \\
\hline Cartoon preparation & 14 & Interactive presentations & 7 \\
\hline Animation & 14 & Avatars & 5 \\
\hline Blog & 9 & Producing videos & 4 \\
\hline
\end{tabular}

As seen in Table 5, pre-service teachers mostly plan to use presentation, cartoon, and animation tools in their future teaching. Exemplar comments for participants` future plans:

I would use GoAnimate, maybe ToonDoo, too. Presentation tools (e. g. Prezi) are necessary in science teaching. When I became a teacher, I plan to use more visual representations. I might use GoAnimate for longer messages and ToonDoo for shorter messages that could be represented in a poster. (S5, Science Education)

I might use Prezi and Voice Thread to present the content in class. I might use ToonDoo for homework to prepare some creative materials. (S2, English Education)

\section{Suggestions}

In this last section of findings, pre-service teachers` suggestions to improve use of these technologies for instruction are presented. Themes from participants comments along with frequencies are presented in Table 6. Many participants suggested having more free options and offering more educational characters and icons for the software. Two other important suggestions were planning use of these technologies in more courses in teacher education programs and training in-service teachers to use these technologies.

Table 6: Pre-service teachers` suggestion for improvement

\begin{tabular}{llll}
\hline Suggestions & $f$ & Suggestions & $f$ \\
\hline Increasing free applications & 7 & More educational applications & 1 \\
\hline Use in other classes & 5 & Offering a shared platform & 1 \\
\hline More character options & 4 & Training in teacher education programs & 1 \\
\hline In-service teacher training & 4 & More educational applications & 1 \\
\hline
\end{tabular}

Some exemplar comments are as follows:

If these tools are used in other classes, too; our learning would be more permanent. I would prefer for in-service teachers to be educated about these technologies, since tablet computers are distributed by government in schools...but many teachers have limited or do not have adequate knowledge and skills to use technology. (S6, Science Education) 
I wish to produce longer videos with the free version of GoAnimate and having more free applications for other software as well. These technologies should be introduced to in-service teachers via seminars and workshops...I believe teachers would be willing to use these tools especially for homework assignments. (S2, English Education)

\section{DISCUSSION}

With the developments in technological capabilities and changing teaching and learning environments, student needs are changing at the same time. Today`s students who embrace and readily learn to use contemporary technologies, easily get bored by traditional teaching methods such as lecturing. Thus, today`s teachers are challenged to find alternative teaching methods and strategies to make their classes more attractive and effective for students. In this new teaching and learning atmosphere, the use of contemporary technologies become more critical. For effective use of technology in education, appropriate course content is an important factor (Goktas, Yildirim \& Yildirim, 2008). In Turkey, development and management of e-content have been discussed more and more with the FATIH project. It is planned to increase the content sharing by teachers in the later stages of the project. However, teachers usually do not have time and competencies to prepare appropriate e-content that aligns well with students` physical, cognitive, and emotional development (Goktas, Yildırım \& Yildırım, 2008). In this regard, practical tools for content development that would take less time and effort and do not require programming skills have crucial importance helping teachers to develop course content.

According to the findings of this study, pre-service teachers believe that their courses would be more effective and efficient when they use tools such as interactive presentations, teacher-produced videos, and animations; which they were introduced in Computer II course. They mentioned some of advantages they foresee when those tools are used as higher student engagement, more visual representation, higher knowledge retention, and being more fun for students. Findings about positive believes of preservice teachers about using information and communication technologies in teaching are consistent with findings of several studies (Aksut, Keyvanoglu \& Balikci, 2013; Aslan \& Zhu, 2016; Baltaci, Goktalay \& Ozdilek, 2010; Hartshorne \& Ajjan, 2009; Hew \& Cheung, 2013). The tools reported by participants as the most beneficial are animation, cartoon, and online presentation tools; which are more colorful, visual, and entertaining comparing to other tools. Participants themselves had fun when changing their characters' emotions with visual impressions, giving them motion, and adding audio recordings to the characters. In their study with pre-service teachers, Kim and Jang (2015) reported that pre-service teachers believed the prominent benefit of Web 2.0 tools would be increasing student motivation via entertaining them, while they are learning.

Some of the challenges pre-service teachers faced during their learning process are reported as: language barrier, some internet skills (such as setting up an email account and creating membership to use some online applications), limited resources available in Turkish, and limited features are available in free versions. While they were developing 
content; they had difficulties in finding characters that are appropriate for the audience, recording for voiceover, spending time and effort, selecting subject and writing scenarios. These findings are parallel to some other research findings. For example, Eyyam, Menevis and Dogruer (2011) posited that even if pre-service teachers had skills to use social networks, they did not have skills to use other web-based applications. Chen, Lim and Tan (2010) argued that pre-service teachers` skills were inadequate for content development such as producing videos, online concept maps, blogs, and so on. Aslan and Zhu (2016) add that pre-service teachers particularly had difficulties in integrating those technologies into teaching and learning process. These results obtained from our study and from other studies urge that although pre-service teachers have basic computer skills (such Word processing, presentation, e-mail, and social networks) when they graduate; they need more preparation for developing e-content; and for integration of the contents they prepared and contents developed by others into instruction effectively.

The most reported reasons by participants for their positive perceptions about positive outcomes of using practical tools for content development are: higher student engagement and higher retention with audio-visuals. They also believe that classes would be more attractive to students, teaching would be more effective via use of multiple teaching methods, and students` technology skills would be improved through use of these technologies. On the other hand, some participants had concerns about if these tools are used regularly, they might cause distraction and/or digression. In this regard; it is critical to plan student outcomes, and appropriate teaching methods and techniques for effective use of these tools. Educators make provision for possible technical problems that may arise during the course. Majority of the participants reported that they plan to use these technologies in their future teaching. The mostly mentioned tools are: presentation, cartoon, and animation tools; which they also found most beneficial. They might have preferred these tools specially to deliver some particular content. For example, animations and cartoons may simplify complex concepts for students, get their attention more, and help for conceptualizing the rigorous content.

Based on the results, we suggest that more close connection and collaboration are needed between MoNE and Schools of Education in universities to guide teachers for effective development and use of instructional content. We believe that it is important to train pre-service teachers about practical tools for content development in Computer II course; and also make them develop content for their content areas in the Educational Technologies and Material Development courses. Additionally, elective courses could be offered for effective technology integration. It is also essential to provide opportunities for pre-service teachers to work collaboratively with in-service teachers to support them for development of instructional content through the Community Service (Topluma Hizmet Uygulamaları) and Teaching Practice (Öğretmenlik Uygulaması) courses. For the MoNE, some suggestions could be: in-service teacher trainings could be improved for development and use of instructional content, it important that teachers are supported by administrators and formator teachers in their districts; teachers who prepare and share instructional content could be rewarded and encouraged; competitions 
could be organized for the content development; the curricula can be updated for the use of such content and use of such technologies. Additionally, further empirical research about impact on student outcomes after the use of instructional content developed by practical tools that are introduced in this study would contribute to the common knowledge. It can be further investigated that why particular tools found more beneficial by pre-service teachers and underlying reasons for their preferences.

\section{REFERENCES}

Aksut, M., Keyvanoglu, A.A. \& Balikci, C. (2013). Sınıf öğretmeni adaylarının bilişim teknolojilerine ilişkin görüşleri. Akademik Bilişim Konferansi, Akdeniz Üniversitesi, Antalya.

Aslan, A., \& Zhu, C. (2016). Investigating variables predicting Turkish pre-service teachers' integration of ICT into teaching practices. British Journal of Educational Technology. doi:10.1111/bjet.12437

Balci, E. O., Gokkaya, Z. \& Kar, A. (2013). FATİH Projesinin üniversiteler yüzü. Istanbul Journal of Social Sciences, 5, 13-30.

Baltaci-Goktalay, S., \& Ozdilek, Z. (2010). Pre-service teachers' perceptions about web 2.0 technologies. Procedia-Social and Behavioral Sciences, 2(2), 4737-4741.

Banoglu, K., Madenoglu, C., Uysal, S., \& Dede, A. (2014). FATİH projesine yonelik ogretmen goruslerinin incelenmesi (Eskisehir ili ornegi). [ An Investigation of Teachers' Perceptions of the Implementation of the FATIH Project (Eskisehir Province Case)]. Egitim Bilimleri Arastırmalar Dergisi (EBAD), 4(1), 39-58.

Besoluk, S., Kurbanoglu, N. I. \& Onder, I. (2010). Educational technology usage of pre- service and in-service science and technology teachers. Elementary Education Online, 9(1), 389-395.

Bulut, I., \& Kocoglu, E. (2012). Sosyal bilgiler öğretmenlerinin akıllı tahta kullanımına ilișkin görüşleri (Diyarbakır ili örneği). Dicle Universitesi Ziya Gokalp Egitim Fakültesi Dergisi, 19, 242-258.

Butler, J. (2012). Grappling with change: Web 2.0 and teacher education. In D. Polly, C. Mims, \& K. A. Persichitte (Eds.), Developing Technology-Rich Teacher Education Programs: Key Issues. IGI Global: Hershey, PA.

Chen, W., Lim, C., \& Tan, A. (2010). Pre-Service teachers' ICT experiences and competencies: New generation of teachers in digital age. In Proceedings of the 18th International Conference on Computers in Education. Putrajaya, Malaysia: Asia-Pacific Society for Computers in Education.

Cicek, M., \& Yazar, B. (2013). Pratik içerik geliştirme teknolojilerinin uzaktan eğitimdeki önemi. Retrieved from http://ab.org.tr/ab13/kitap/eski/118.pdf on 04.02.2016.

Creswell, J.W. (2013). Research design: Qualitative, quantitative, and mixed methods approaches $\left(4^{\text {th }}\right)$ ed.). USA: Sage.

Cuhadar, C. \& Yucel, M. (2010). Yabancı dil öğretmeni adaylarının bilgi ve iletişim teknolojilerinin öğretim amaçlı kullanımına yönelik özyeterlik algıları. Pamukkale Üniversitesi Eğitim Fakültesi Dergisi, 27, 199-210.

Eren, E., Yurtseven Avci, Z., \& Seckin Kapucu, M. (2014). Developing a scale for competencies and perceptions of necessity about using practical tools for content development. Journal of Theory and Practice in Education (JTPE), 10 (5), 1177-1189. 
Eren, E., Yurtseven Avci, Z., \& Seckin Kapucu, M. (2015). Pre-Service Teachers Competencies and Perceptions of Necessity about Practical Tools for Content Development. International Journal of Instruction, 8(1), 92-103.

Eyyam, R., Menevis, I. \& Dogruer, N. (2011). Perceptions of teacher candidates towards Web 2.0 technologies, Procedia Social and Behavioral Sciences, 15, 2663-2666.

Glesne, C. (1999). Becoming qualitative researchers: An introduction (2nd ed.). Don Mills, Ontario, Canada: Longman.

Goktas, Y., Yildirim, Z., \& Yildirim, S. (2008). A review of ICT related courses in pre-service teacher education programs. Asia Pacific Education Review, 9(2), 168-179.

Goktas, Y., Yildirim, S. \& Yildirim, Z. (2009). Main barriers and possible enablers of ICT integration into preservice teacher education programs. Educational Technology \& Society, 12(1), 193-204.

Hartshorne, R., \& Ajjan, H. (2009). Examining student decisions to adopt Web 2.0 technologies: theory and empirical tests. Journal of computing in higher education, 21(3), 183-198.

Hew, K. F. \& Cheung, W. S. (2013). Use of Web 2.0 technologies in K-12 and higher education: The search for evidence-based practice. Educational Research Review, 9, 47-64.

Kayaduman, H., Sarıkaya, M. \& Seferoglu, S. S. (2011). Eğitimde FATíH projesinin öğretmenlerin yeterlik durumları açısından incelenmesi. Akademik Bilişim Konferansı, 2-4 Şubat /İnönü Üniversitesi, Malatya.

Keles, E., Oksuz, B. D. \& Bahcekapili, T. (2013). Teknolojinin eğitimde kullanılmasına ilişkin öğretmen görüşleri: FATİH projesi örneği. Gaziantep University Journal of Sciences, 12 (2), 353366.

Kim, H.J.\&Jang, H.Y. (2015). Motivating pre-service teachers in technology integration of web 2.0 for teaching internships. International Education Studies, 8(8), 21-32.

Kurt, A. A., Kuzu. A, Dursun, O. O., Gullepınar, F., \& Gultekin, M. (2013). FATIH projesinin pilot uygulama sürecinin değerlendirilmesi: Öğretmen görüşleri. Journal of Instructional Technologies \& Teacher Education, 2(1).

Meyer, K. A. (2010). A comparison of Web 2.0 tools in a doctoral course. Internet and Higher Education, 13, 226-232.

Miles, M. B., \& Huberman, A. M. (1994). Qualitative data analysis: An expanded sourcebook. Sage.

Murugesan, S. (2007). Understanding Web 2.0. IT professional, 9(4), 34-41.

Prensky, M. (2001). Digital Natives, Digital Immigrants. On the Horizon, 9(5), 1-6.

Selvi, K. (2010). Teachers' competencies. Cultura International Journal of Philosophy of Culture and Axiology, 7(1), 167-175.

Tondeur, J., van Braak, J., Sang, G., Voogt, J., Fisser, P., \& Ottenbreit-Leftwich, A. (2012). Preparing pre-service teachers to integrate technology in education: A synthesis of qualitative evidence. Computers \& Education, 59(1), 134-144.

Xiong, X. B., \& Lim, C. P. (2015). Rethinking the Impacts of Teacher Education Program on Building the ICT in Education Competencies of Pre-service Teachers: A Case of Teacher Education in Mainland China. Journal of Applied Research in Education, 19, 25-35. 


\section{Turkish Abstract \\ İçerik Geliştirme için Pratik Araçlar: Stajyer Öğrencilerin Deneyimleri ve Algıları}

$\mathrm{Bu}$ çalışma içerik geliştirme için Pratik araçları kullanmak konusunda stajyer öğrencilerin deneyimlerini ve algılarını araştırmayı amaçlayan araştırma desenei olarak fenomenolojiyi kullanan bir çalışmadır. Katılımcılar Türkiye'de bir devlet üniversitesinde 2013-2014 bahar yarıyılında Bilgisayar II dersini alan 24 stajyer öğrencidir. Ders sirasında yükleme ve bilgisayar programlama becerileri gerektirmeyen genellikle internet-tabanlı teknolojiler olarak tanımlanan birkaç pratik araç katılımcılara tanıtılmıştır. Öğrenciler ödevleri ve projeleri için alanlarına özgü içerikler geliștirmişlerdir. Verileri analiz etmek için içerik analizi kullanılmıştır. Bulgular katılımcıların bu araçları kullanarak içerik geliştirmeyi sevdiklerini ortaya çıkarmıştır. Aynı zamanda bazı zorluklarla karşılaşmışlardır. Katılımcıların çoğu sunum, animasyon ve karikatür oluşturma araçlarının öğrenci öğrenmesini geliştirmede en yaralı araçlar olduklarını belirtmişlerdir. Katılımcıların bu araçlar sınıfta kullanılırsa bekledikleri olumlu öngörüleri: yüksek öğrenci katılımı, aktif katılım, destekleme, daha derin kavrayış, hayal etme becerilerinin gelişmesidir. Bu çalışmanın içerik geliştirme için etkili teknoloji kullanımınn öğretmen yetiştirme programlarının geliştirilmesinde katkı sağlayacağı düşünülmektedir.

Anahtar Kelimeler: stajyer öğrenciler, pratik araçlar, içerik geliştirme, deneyim, algı, Web 2.0.

French Abstract

Outils Pratiques pour Développement Content du contenu : Pré entretenez Professeurs : Expériences et Perceptions

Cette étude adopte l'approche de phénoménologie comme la méthode de design de recherche d'examiner des professeurs de pré service 'des expériences et des perceptions en utilisation d'outils pratiques pour le développement du contenu. Les participants sont vingt-quatre professeurs de préservice qui prenaient l'Ordinateur II cours pendant 2013-2014 semestre de printemps à une université publique en Turquie. Pendant le cours, ils ont été présentés plusieurs outils pratiques, que nous définissons comme les technologies surtout à base d'Internet qui n'exigent pas d'installation ou ayant de compétences de programmation informatique. Pré entretenez des professeurs a préparé le contenu spécifique à leurs champs pour des devoirs et des projets. À la fin des entretiens individuel de semestre ont été conduits avec les participants. La méthode d'analyse de contenu a été utilisée pour analyser les données. Selon les résultats, ils ont aimé créer le contenu utilisant ces outils. En même temps, ils avaient quelques difficultés. La Majorité des participants perçoit la présentation, l'animation, des outils de création de dessin animé pour être la plus avantageuse pour améliorer l'apprentissage d'étudiant. Certains des résultats positifs qu'ils prévoient quand ces technologies sont utilisées dans la salle de classe sont : engagement d'étudiant plus haut, participation active, renforcement, compréhension plus profonde et développement de compétences d'imagination. On estime que les découvertes de cette étude contribueront au développement de programmes de préparation de professeur pour l'utilisation effective de technologie particulièrement pour le développement du contenu.

Mots Clés: pré entretenez des professeurs, des outils pratiques, contentez le développement, l'expérience, la perception, le Web 2.0.

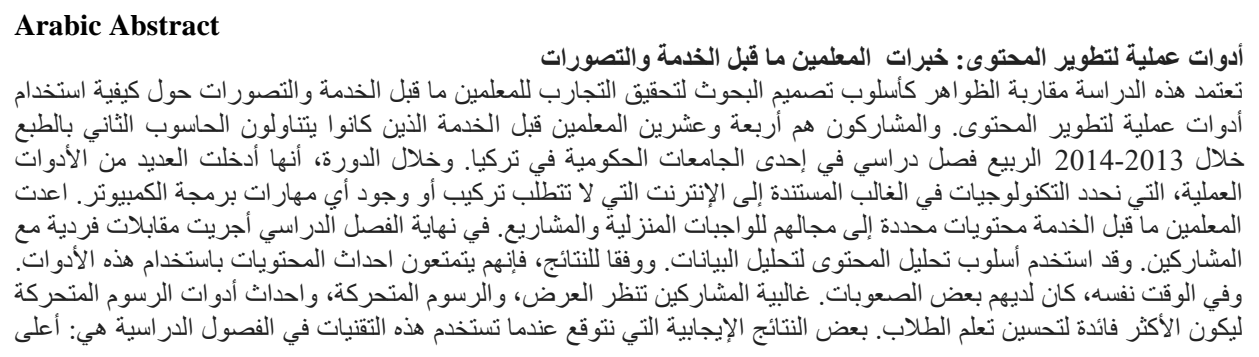




$$
\begin{aligned}
& \text { مشاركة الطلاب، والمشاركة النشطة، التعزيز، فهم أعمق، وتنمية مهارات الخيال. ويتقق أن النتائج التي توصلت إليها هذه الدراسة }
\end{aligned}
$$

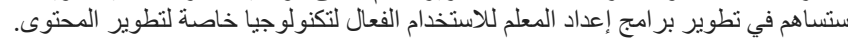

$$
\begin{aligned}
& \text { كلمات البحث: المعلمين ماقبل الخدمة، والأدو ات العملية، وتطوير المحتوى و الخبرة و الإدر الك، الويب } 2.0 .
\end{aligned}
$$

German Abstract

Praktische Werkzeuge für die Content-Entwicklung: die Erfahrungen und Wahrnehmungen der Preservice Lehrer

Diese Studie nimmt Phänomenologie Ansatz als Methode Forschungsdesign, die Erfahrungen und Wahrnehmungen der Pre-Service-Lehrer anhand von praktischen Tools für die Entwicklung von Inhalten zu untersuchen. Die Teilnehmer waren vierundzwanzig Pre-Service-Lehrer, die Computer-II Kurs in der Türkei an einer öffentlichen Universität während 2013-2014 Frühlingssemester nahm. Während des Kurses wurden sie mehrere praktische Werkzeuge eingeführt, die wir als meist internetbasierte Technologien definieren, die keine Installation erfordert oder keine Computerprogrammierkenntnisse. Preservice Lehrer vorbereitet Inhalte speziell auf ihre Facher für die Hausaufgaben und Projekte. Am Ende des Semesters Einzelinterviews wurden mit den Teilnehmern durchgeführt. Die Content-Analyse-Methode wurde verwendet, um die Daten zu analysieren. Nach den Ergebnissen, genossen sie Inhalte mit diesen Tools zu schaffen. Zur gleichen Zeit hatten sie einige Schwierigkeiten. Die Mehrheit der Teilnehmer wahrnehmen Präsentation, Animation, Cartoonerstellungswerkzeuge die meisten vorteilhaft für Lernen der Schüler zu verbessern. Einige der positiven Ergebnisse sie vorhersehen, wenn diese Technologien im Unterricht verwendet werden, sind: höhere Schülerbeteiligung, aktive Teilnahme, Verstärkung, ein tieferes Verständnis und die Entwicklung von Phantasie Fähigkeiten. Es wird angenommen, dass die Ergebnisse dieser Studie zur Entwicklung der Lehrervorbereitungsprogramme für die effektive Nutzung von Technologie vor allem für die Entwicklung von Inhalten beitragen.

Schlüsselwörter: pre-service-lehrer, praktische werkzeuge, content-entwicklung, erfahrung, wahrnehmung, Web 2.0.

\section{Malaysian Abstract \\ Alat praktikal untuk Pembangunan Kandungan: Pengalaman dan persepsi Guru Pra Perkhidmatan}

Kajian ini menggunakan pendekatan fenomenologi sebagai kaedah reka bentuk kajian untuk menyiasat pengalaman dan persepsi guru pra perkhidmatan mengenai penggunaan alat praktikal untuk pembangunan kandungan. Para peserta adalah dua puluh empat guru pra perkhidmatan yang mengambil Komputer Kursus II semasa 2013-2014 spring semester di sebuah universiti awam di Turki. Semasa kursus tersebut, mereka telah diperkenalkan dengan beberapa alat praktikal, yang mana dikenal pasti sebagai teknologi yang kebanyakannya berasaskan internet yang tidak memerlukan pemasangan atau mempunyai apa-apa kemahiran pengaturcaraan komputer. Guru-guru pra-perkhidmatan yang menyediakan kandungan khusus untuk bidang masing-masing sebagai kerja rumah dan projek. Pada akhir semester temu bual individu telah dijalankan dengan para peserta. Kaedah analisis kandungan digunakan untuk menganalisis data. Menurut hasil kajian, mereka seronok apabila mencipta kandungan menggunakan alat ini. Pada masa yang sama, mereka mempunyai beberapa kesukaran. Majoriti peserta melihat persembahan, animasi, alat penciptaan kartun yang paling bermanfaat untuk meningkatkan pembelajaran pelajar. Sebahagian daripada hasil positif yang dijangkakan apabila teknologi ini digunakan di dalam bilik darjah ialah: penglibatan lebih tinggi pelajar, penyertaan aktif, pengukuhan, pemahaman yang lebih mendalam, dan pembangunan kemahiran imaginasi. Adalah dipercayai bahawa hasil kajian ini akan menyumbang kepada pembangunan program sebagai persediaan guru melalui penggunaan teknologi yang berkesan terutamanya bagi pembangunan kandungan.

Kata Kunci: guru pra perkhidmatan, alat praktikal, pembangunan kandungan, pengalaman, persepsi, Web 2.0. 